\title{
THE SURFACE TEXTURE OF HARDENED 18CrMo4 STEEL AFTER TURNING WITH PLUNGE FEED
}

\author{
Bogusław Pytlak
}

\begin{abstract}
S u m m a r y
A research results of surface texture after finish turning operation with plunge feed of hardened $18 \mathrm{CrMo} 4$ steel with use of cubical boron nitride (CBN) inserts having Wiper geometry are presented in this paper. The research was conducted according to Taguchi methodology, especially for mating of the machined surface with radial shaft seals. Next, the surface after finish turning with plunge feed was compared with the surface after plunge grinding, while assessment indicators used to this purpose testify a substantial similarity of the two surfaces.

Keywords: hard turning with plunge feed, plunge grinding, surface texture, radial shaft seals
\end{abstract}

\author{
Struktura geometryczna powierzchni stali 18CrMo4 \\ w stanie zahartowanym po toczeniu z posuwem wgłębnym \\ Streszczenie
}

W pracy przedstawiono wyniki badań struktury geometrycznej powierzchni po operacji toczenia wykończeniowego $z$ posuwem wgłębnym stali $18 \mathrm{CrMo} 4$ w stanie zahartowanym płytkami z regularnego azotku boru $(\mathrm{CBN})$ o geometrii typu Wiper. W badaniach stosowano metodykę Taguchi'ego. Uwzględniono współpracę obrobionej powierzchni z wargowymi pierścieniami uszczelniającymi. Porównano stan powierzchni po toczeniu wykończeniowym z posuwem wgłębnym i powierzchni po szlifowaniu wgłębnym. Wartości przyjętych wskaźników oceny świadczą o znacznym podobieństwie obu powierzchni.

Słowa kluczowe: toczenie na twardo z posuwem wgłębnym, szlifowanie wgłębne, struktura geometryczna powierzchni, wargowe pierścienie uszczelniające

\section{Introduction}

The problem of finishing operations of a surfaces mating with radial shaft seals (Simmerring ring) is known for a long time and was discussed in the [1-3]. Especially, it concerns the shafts made from $18 \mathrm{CrMo} 4$ alloy steel with low contents of carbon, often used as a material for toothed elements in Poland. The surfaces mating with the radial shaft seals should fulfill suitable requirements in relation to dimensional accuracy and properties of surface layer [4-6]. In most cases, the requirements are as follows: type of fit - slide fit (h), accuracy class -

Address: Bogusław PYTLAK, PhD Eng., University of Bielsko-Biała, Department of Manufacturing Technology and Automation, 43-309 Bielsko-Biała, Willowa 2, Poland, phone: +48 338279 213, fax: +48 338279 300, e-mail: bpytlak@ath.bielsko.pl 
IT11, radial run-out $\Delta b$ dependent on rotation speed (e.g. for $n=1500 \mathrm{rpm}-\Delta b$ $\leq 0.2 \mathrm{~mm}$ ), hardness - about 55HRC, and surface roughness described by the parameters $R_{a}=0.2 \div 0.8 \mu \mathrm{m}, R_{z}=1 \div 4 \mu \mathrm{m}, R_{\max } \leq 6.3 \mu \mathrm{m}$ [3-6].

In up-to-now industrial practice, as finishing operation of the surface mating with the radial shaft seals is the most often used the plunge grinding with suitably long time of sparking out, which is recommended by most manufacturers of the radial shaft seals. Owing to it, surface texture free from helical machining marks is generated. However, in the recent years the finish hard turning has become more and more popular, which brings many potential benefits [7]. It allows to reduce set up costs of machine tool, machining time, capital costs of the machine tool [3], and eliminate coolants, what at present environmental restrictions is very important [8-11]. The hard turning process has a certain disadvantages. Apart from very high tooling costs, to the most important belongs generation of helical machining marks, which in some measure results from definition of the turning process itself. In this paper, in order to eliminate this phenomenon, the hard turning operation with plunge feed was applied. Shortening of machining time belongs to additional benefits. For example, time of the turning with longitudinal feed of a surface under synchromesh for a normal insert amounts to 2.2 seconds, for the Wiper insert is 0.73 second, while the turning with plunge feed takes $0.04 \mathrm{~s}$ only [12]. The hard turning with plunge feed has a restriction in form of width of the machined surface, which should be equal to length of cutting edge of the insert. In case of the surfaces mating with the radial shaft seals it is not an obstacle, because contact of the rotary seal with surface of the shaft occurs on very small width.

\section{Methodology}

In the paper an effect of the cutting speed $v_{c}$, feed $f$ being simultaneously depth of the cut $a_{p}$, and displacement $p$ on a chosen surface roughness parameters was investigated: average roughness $R_{a}$, mean roughness depth $R_{z}$ and maximum roughness depth $R_{\max }$ were taken into account. The displacement $p$ consists in a small movement of the insert along its cutting edge, aimed at elimination of effects of profile roughness of the cutting edge on the machined surface [12]. It occurs after completion of the in-feed movement of the cutting insert. In the next machining step a dwell equal to two shaft rotations is performed, aimed at assurance of adequate dimensional accuracy of the machined surface.

The experimental study was performed with use of Taguchi methodology. This methodology allows a simple, efficient, and systematic improvement of product quality and/or decrease of its machining costs by using experimental research. Traditional designs of the experiment are complicated and difficult in use. Additionally, when number of input parameters increases it is necessary to 
perform large number of experiments [13]. Orthogonal arrays designed by Taguchi allow simultaneous and independent assessment of influence of two or more input parameters on the output parameter when minimal number of experiments is performed. In Taguchi methodology the lost function is defined being the difference between desired value and experimental value. In turn, the lost function can be transformed to signal-to-noise $S / N$ ratio, which depending on characteristic of examined quantity can be: the smaller-the better, the biggerthe better, and the nominal-the better. Values of the signal-to-noise $S / N$ ratio for the parameters $R_{a}, R_{z}$ and $R_{\max }$ were calculated assuming criterion the smaller the better (SB), with use of the equation [14]:

$$
S / N_{S B}=-10 \log \left(\frac{1}{n} \sum_{i=1}^{n} y_{i}^{2}\right)
$$

where: $n$ - number of the measurements for a given layout of the experiment's design, $y_{i}-$ measured value of the investigated parameter.

To the experimental research three setting values of the cutting parameters were taken $v_{c}=100,150,200 \mathrm{~m} / \mathrm{min}, f=0.05,0.075,0.1 \mathrm{~mm} / \mathrm{rev}$ and $p=$ $0,0.05,0.1 \mathrm{~mm}$, successively referred as level 1,2 and 3 . The experimental research was conducted according to the experiment's design based on the orthogonal array $\mathrm{L}_{9}$ (Table 1). For each layout of the experiment's design 3 repetitions were performed.

Table 1. Setting values of the cutting parameters for particular layouts of the experiment's design based on the orthogonal array $\mathrm{L}_{9}$

\begin{tabular}{|c|c|c|c|}
\hline \multirow{2}{*}{$\begin{array}{c}\text { Layout } \\
\text { No. }\end{array}$} & \multicolumn{3}{|c|}{ Cutting parameters } \\
\cline { 2 - 4 } & $\boldsymbol{v}_{\boldsymbol{c}}, \mathbf{m} / \mathbf{m i n}$ & $\boldsymbol{f}, \mathbf{m m} / \mathbf{r e v}$ & $\boldsymbol{p}, \mathbf{m m}$ \\
\hline 1 & 100 & 0.05 & 0 \\
\hline 2 & 100 & 0.075 & 0.05 \\
\hline 3 & 100 & 0.1 & 0.1 \\
\hline 4 & 150 & 0.05 & 0.05 \\
\hline 5 & 150 & 0.075 & 0.1 \\
\hline 6 & 150 & 0.1 & 0.1 \\
\hline 7 & 200 & 0.05 & 0 \\
\hline 8 & 200 & 0.075 & 0.05 \\
\hline 9 & 200 & 0.1 & \\
\hline
\end{tabular}

The research was conducted on the shaft having dimensions of $\varnothing 60 \times 300$ $\mathrm{mm}$, made from $18 \mathrm{CrMo} 4$ steel. On the shaft 27 grooves with dimension of $4 \times 4 \mathrm{~mm}$ were cut (Fig. 1), what created 27 cylindrical surfaces with $6 \mathrm{~mm}$ width (9 layouts of the design $\times 3$ repetitions), used in course of the research. 
In the next step the shaft underwent the following thermo-chemical treatments: carburizing to the depth of $2 \mathrm{~mm}$, hardening and tempering to the hardness of $59 \pm 2 \mathrm{HRC}$. The machining was carried out on the CNC lathe of TUG 56-MN type (AFM-Andrychów Co.). To finishing hard turning monolithic cubical boron nitride (CBN) inserts of TNGX1103085S-R-WZ type were used with patented Crossbill ${ }^{\mathrm{TM}}$ Wiper geometry [15], which were clamped in the tool holder of CTJNR 2525 M11 type (Fig. 2).

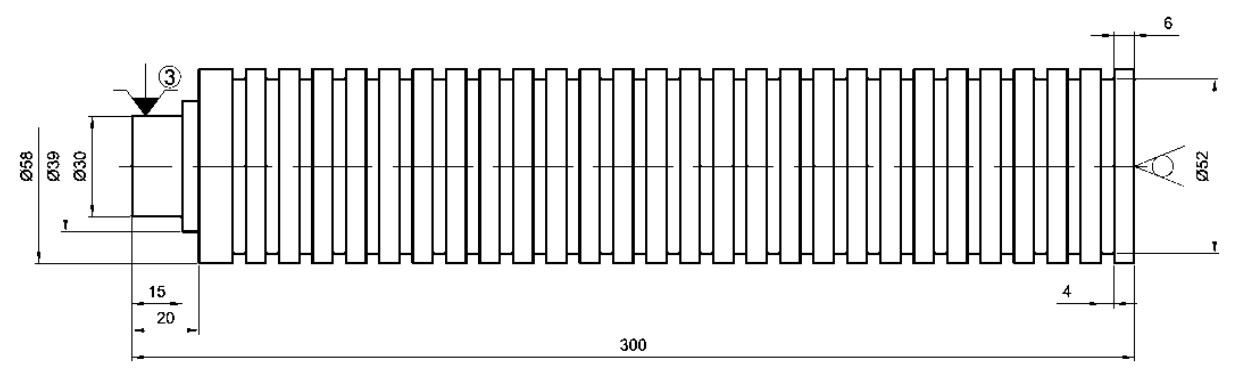

Fig. 1. Shape and dimensions of the specimens made from $18 \mathrm{CrMo} 4$ steel used to the research

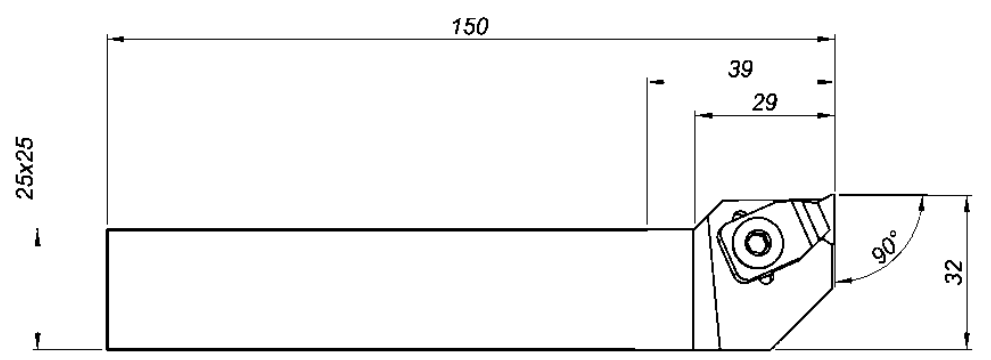

Fig. 2. The insert with Wiper geometry (TNGX1103085S-R-WZ) clamped in the CTFNR 2525M11 tool holder of Seco Co. [15]

Measurements of surface roughness were made with the Mahr Pethometer Concept profile measurement gauge. The surface roughness was measured in 3 places, arranged uniformly on circumference of the shaft (every $120^{\circ}$ ), for each from three repetitions of the experiment's design layout. During the measurement the original profile was recorded, from which, using the Pethometer Concept 7.0-19 software, it was possible to determine values of any parameters of surface roughness and waviness. The measurements were carried out with measuring length of $l_{m}=1.25 \mathrm{~mm}$ and sampling length of $l_{r}=0.25 \mathrm{~mm}$, equal to limiting wavelength $\lambda_{c}$ (cut-off) for the filter described in [16]. In course of the measurements the stylus with radius $2 \mu \mathrm{m}$ moving with speed $v_{o s}=0.5 \mathrm{~mm} / \mathrm{s}$ was used. Whereas, measurements of the topography were carried 
out with use of the PKT measuring table. The surface with the dimensions of $1.25 \times 1.25 \mathrm{~mm}$ was evaluated, making 626 sections at intervals of $2 \mu \mathrm{m}$.

Evaluation of the results was carried out using "Statistica" software. To evaluation of the surface roughness the following parameters were taken: $R_{a}, R_{z}$ and $R_{\max }[17]$.

\section{Results and their analysis}

Mean values of surface roughness parameters $R_{a}, R_{z}$ and $R_{\max }$, and corresponding $S / N_{S B}$ ratio after turning with plunge feed obtained from the measurements are given in the Table 2 . The surface turned with the plunge feed can be characterized by the surface roughness parameters: $R_{a}, R_{z}$ and $R_{\max }$, smaller than those recommended by radial shaft seals manufacturers. Moreover, differences within accomplished design of the experiment, between maximal and minimal average value of the parameter are minimal, and amount to $R_{a}-0.016$ $\mu \mathrm{m}, R_{z}-0.084 \mu \mathrm{m}$ and $R_{\max }-0.103 \mu \mathrm{m}$ respectively. This shows about very little effect of particular cutting parameters on resulting surface roughness, what in turn can be confirmed by close to each other values of the $S / N_{S B}$ ratio. The values of surface roughness parameters $R_{a}, R_{z}$ and $R_{\max }$ are slightly smaller than the parameters of the surface roughness after plunge grinding [18].

Table 2. The mean values from the measurements of surface roughness parameters

$R_{a}, R_{z}$ and $R_{\max }$ and corresponding $S / N_{S B}$ ratio after turning with plunge feed

\begin{tabular}{|c|c|c|c|c|c|c|}
\hline $\begin{array}{c}\text { Layout } \\
\text { No. }\end{array}$ & $\boldsymbol{R}_{\boldsymbol{a}}, \boldsymbol{\mu \mathbf { m }}$ & $\begin{array}{c}\boldsymbol{S} / \boldsymbol{N}_{\boldsymbol{S B}}, \mathbf{d B} \\
\text { for } \boldsymbol{R}_{\boldsymbol{a}}\end{array}$ & $\boldsymbol{R}_{\boldsymbol{z}}, \boldsymbol{\mu \mathbf { m }}$ & $\begin{array}{c}\boldsymbol{S} / \boldsymbol{N}_{\boldsymbol{S B} \boldsymbol{B}}, \mathbf{d B} \\
\text { for } \boldsymbol{R}_{\boldsymbol{z}}\end{array}$ & $\boldsymbol{R}_{\max }, \boldsymbol{\mu m}$ & $\begin{array}{c}\boldsymbol{S} / \boldsymbol{N}_{\boldsymbol{S B}}, \mathbf{d B} \\
\text { for } \boldsymbol{R}_{\max }\end{array}$ \\
\hline 1 & 0.060 & 24.228 & 0.357 & 8.800 & 0.526 & 5.269 \\
\hline 2 & 0.059 & 24.559 & 0.364 & 8.723 & 0.493 & 5.795 \\
\hline 3 & 0.057 & 24.844 & 0.341 & 9.318 & 0.478 & 6.247 \\
\hline 4 & 0.060 & 24.305 & 0.356 & 8.932 & 0.477 & 6.207 \\
\hline 5 & 0.052 & 25.546 & 0.328 & 9.642 & 0.464 & 6.365 \\
\hline 6 & 0.056 & 24.949 & 0.350 & 8.997 & 0.474 & 6.223 \\
\hline 7 & 0.068 & 23.362 & 0.412 & 7.688 & 0.568 & 4.892 \\
\hline 8 & 0.060 & 24.410 & 0.378 & 8.437 & 0.531 & 5.427 \\
\hline 9 & 0.062 & 24.052 & 0.399 & 7.942 & 0.560 & 4.985 \\
\hline
\end{tabular}

In the Tables 3, 4 and 5 mean values of the $S / N_{S B}$ ratio for particular set-up levels of cutting parameters for the surface roughness parameters $R_{a}, R_{z}$ and $R_{\max }$ are presented. In addition, these tables comprise difference between maximal and minimal value of the $S / N_{S B \max }-S / N_{S B \min }$ ratio and total mean value of the $S / N_{S B}$ ratio calculated for each cutting parameter.

Analysis of the tables 3-5 shows, that optimal setting levels of the cutting parameters (the highest value of the $S / N_{S B}$ ) are as follows: $v_{c}=150 \mathrm{~m} / \mathrm{min}$, 
$f=0.075 \mathrm{~mm} / \mathrm{rev}$ and $p=0.1 \mathrm{~mm}$. This corresponds to the experiment's design layout No. 5 (Tab. 1). Repeatability of the optimal parameters for particular surface roughness parameters results from their interdependence, and from the fact that they describe, in a slightly different way, the same surface. It should be noted another very important feature manifested by slight differences between maximal and minimal value of the $S / N_{S B \max }-S / N_{S B \min }$ ratio, what points at very small significance of influence of particular cutting parameters on a chosen surface roughness parameters.

Table 3. The mean values of the $S / N_{S B}$ ratio for particular setting levels of cutting parameters for arithmetic mean of the roughness $R_{a}$

\begin{tabular}{|c|c|c|c|c|}
\hline \multirow{2}{*}{$\begin{array}{c}\text { Cutting } \\
\text { parameter }\end{array}$} & \multicolumn{3}{|c|}{ Mean value $\boldsymbol{S} / \boldsymbol{N}_{\boldsymbol{S B}}, \mathbf{d B}$} & \multirow{2}{*}{$\boldsymbol{S} / \boldsymbol{N}_{\boldsymbol{S B} \text { max }}-\boldsymbol{S} / \boldsymbol{N}_{\boldsymbol{S B} \text { min }}$} \\
\cline { 2 - 4 } & level 1 & level 2 & level 3 & 0.991 \\
\hline$v_{c}, \mathrm{~m} / \mathrm{min}$ & 24.544 & 24.933 & 23.942 & 0.873 \\
\hline$f, \mathrm{~mm} / \mathrm{rev}$ & 23.965 & 24.838 & 24.615 & 0.278 \\
\hline$p, \mathrm{~mm}$ & 24.529 & 24.306 & 24.584 & - optimal level \\
\hline \multicolumn{4}{r}{ Total mean ratio $S / N_{S B}=24.473 \mathrm{~dB} ;$} \\
\hline
\end{tabular}

Table 4. The mean values of the $S / N_{S B}$ ratio for particular setting levels of cutting parameters for mean roughness depth $R_{z}$

\begin{tabular}{|c|c|c|c|c|}
\hline \multirow{2}{*}{$\begin{array}{c}\text { Cutting } \\
\text { parameter }\end{array}$} & \multicolumn{3}{|c|}{ Mean value $\boldsymbol{S} / \boldsymbol{N}_{\boldsymbol{S B}}, \mathbf{d B}$} & \multirow{2}{*}{$\boldsymbol{S} / \boldsymbol{N}_{\boldsymbol{S B} \text { max }}-\boldsymbol{S} / \boldsymbol{N}_{\boldsymbol{S B} \text { min }}$} \\
\cline { 2 - 4 } & level 1 & level 2 & level 3 & 1.168 \\
\hline$v_{c}, \mathrm{~m} / \mathrm{min}$ & 8.947 & 9.190 & 8.022 & 0.461 \\
\hline$f, \mathrm{~mm} / \mathrm{rev}$ & 8.473 & 8.934 & 8.752 & 0.351 \\
\hline$p, \mathrm{~mm}$ & 8.745 & 8.532 & 8.883 & - optimal level \\
\hline \multicolumn{4}{|c|}{ Total mean ratio $S / N_{S B}=8.720 \mathrm{~dB} ;$} \\
\hline
\end{tabular}

Table 5. The mean values of the $S / N_{S B}$ for particular setting levels of cutting parameters for maximal roughness depth $R_{\max }$

\begin{tabular}{|c|c|c|c|c|}
\hline \multirow{2}{*}{$\begin{array}{c}\text { Cutting } \\
\text { parameter }\end{array}$} & \multicolumn{3}{|c|}{ Mean value $S / \boldsymbol{N}_{\boldsymbol{S B}}, \mathbf{d B}$} & \multirow{2}{*}{$\boldsymbol{S} / \boldsymbol{N}_{\boldsymbol{S B} \text { max }}-\boldsymbol{S} / \boldsymbol{N}_{\boldsymbol{S B} \text { min }}$} \\
\cline { 2 - 4 } & level 1 & level 2 & level 3 & 1.164 \\
\hline$v_{c}, \mathrm{~m} / \mathrm{min}$ & 5.770 & 6.265 & 5.101 & 0.406 \\
\hline$f, \mathrm{~mm} / \mathrm{rev}$ & 5.456 & 5.862 & 5.818 & 0.195 \\
\hline$p, \mathrm{~mm}$ & 5.640 & 5.662 & 5.835 & - optimal level \\
\hline \multicolumn{4}{|c|}{ Total mean ratio $S / N_{S B}=5.712 \mathrm{~dB} ;$} \\
\hline
\end{tabular}

Summarizing the above experimental results, the cutting speed $v_{c}$ (the biggest difference between the ratios $S / N_{S B \max }-S / N_{S B \text { min }}$ ), has the most significant effect on a chosen surface roughness parameters. In general, its increase results in a minimal increase of the surface roughness. The feed $f$ is virtually without any effect, because it doesn't take part in shaping of the 
surface texture. In turn, the displacement $p$ should theoretically have such effect, but the smallest differences of $S / N_{S B \max }-S / N_{S B \text { min }}$ ratio for these parameters testify for a different situation, what could be explained by excellent finishing quality of the cutting edge and lacking need of the displacement $p$, at least during initial time period of wear of the inserts.

The Figure 3 shows an example of surface roughness profile and material portion curve for a surface machined with optimal values of cutting parameters: $v_{c}=150 \mathrm{~m} / \mathrm{min}, f=0.075 \mathrm{~mm} / \mathrm{rev}, p=0.1 \mathrm{~mm}$.

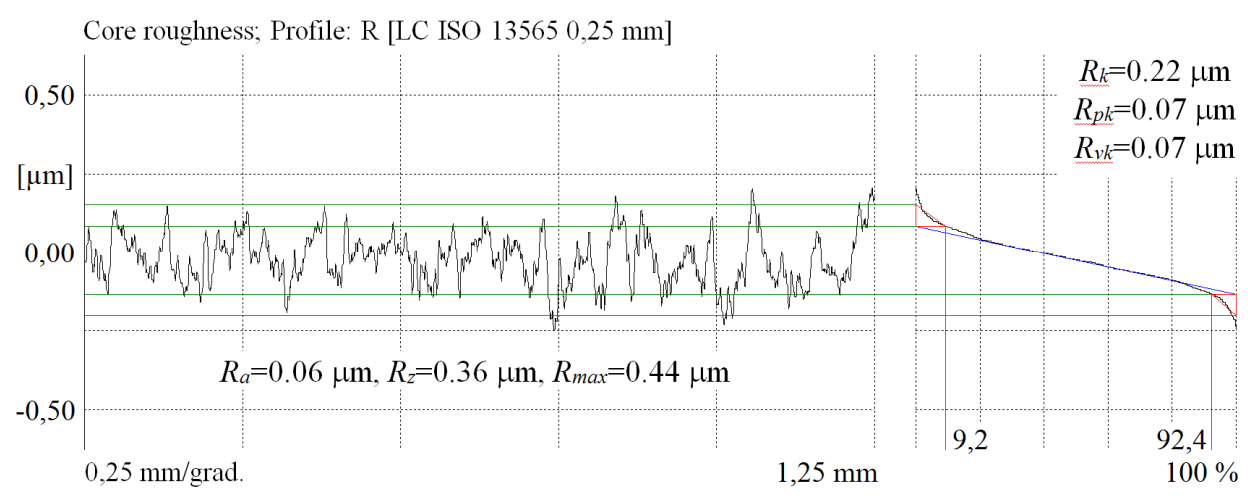

Fig. 3. The roughness profile and material portion curve for a surface turned with plunge feed for optimal values of cutting parameters: $v_{c}=150 \mathrm{~m} / \mathrm{min}, f=0.075 \mathrm{~mm} / \mathrm{rev}, p=0.1 \mathrm{~mm}$

In order to compare 3D geometrical surface texture after turning with plunge feed and the surface texture after the plunge grinding described in work [18], it have been made isometric images of the both surfaces (Fig. 4). In turn, the Fig. 5 shows the charts of the surface material portion curve of the both above mentioned surfaces. The surface material portion curve after turning with plunge feed can be characterized by a slightly larger inclination (parameter $S_{k}$ higher by $0.14 \mu \mathrm{m}$ ) and slightly deeper valleys (parameter $S_{v k}$ higher by 0.02 $\mu \mathrm{m}$ ) in comparison to the surface after plunge grinding. However, height of the peaks on the both surfaces is the same and amounts to $S_{p k}=0.01 \mu \mathrm{m}$.

To better identify the 3D surface texture after different kinds of finish machining presented in work [18], the following parameters were assumed for assessment of the surfaces mating with the radial shaft seals: ratio of maximal peak height to maximal height of roughness area $S_{p} / S_{t}$ (emptiness coefficient) and ratio of core height to maximum height of the roughness area $S_{k} / S_{t}$. Value of the $S_{p} / S_{t}$ ratio for the surface after turning with plunge feed is slightly higher and amounts to $S_{p} / S_{t}=0.50$, and after grinding $S_{p} / S_{t}=0.47$, which means that turned surface is characterized by a higher relative height of peaks area. Analysis of the parameter $S_{k} / S_{t}$ looks similarly, in case of the turning with plunge feed the $S_{k} / S_{t}$ 
amounts to 0.48 , while for grinding the $S_{k} / S_{t}=0.44$. This means that relative core height of the roughness is greater than the roughness of the turned surface.

a)

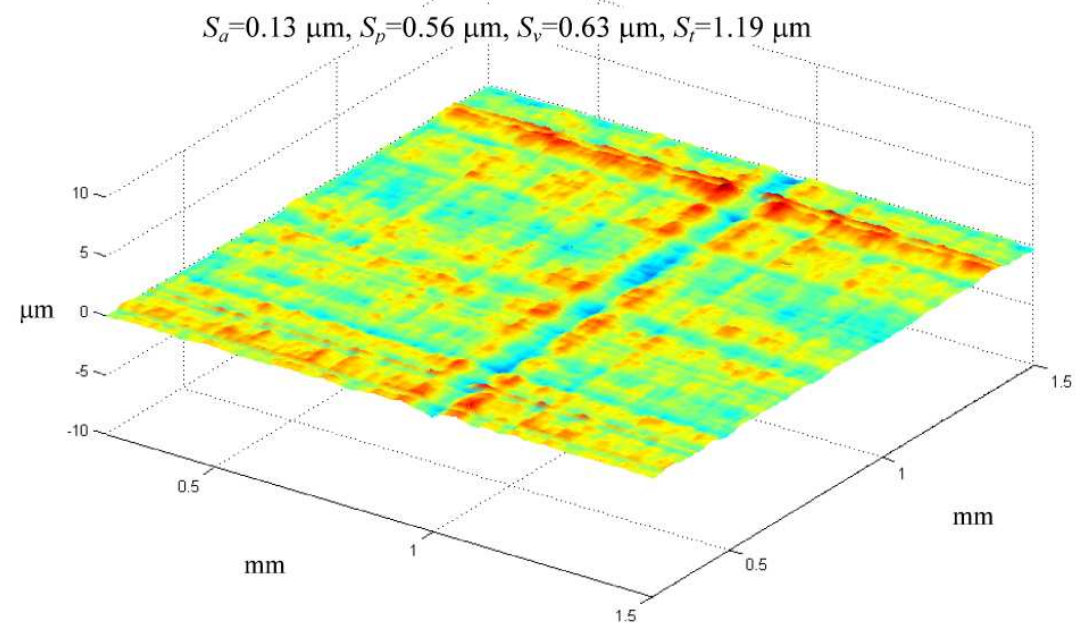

b)

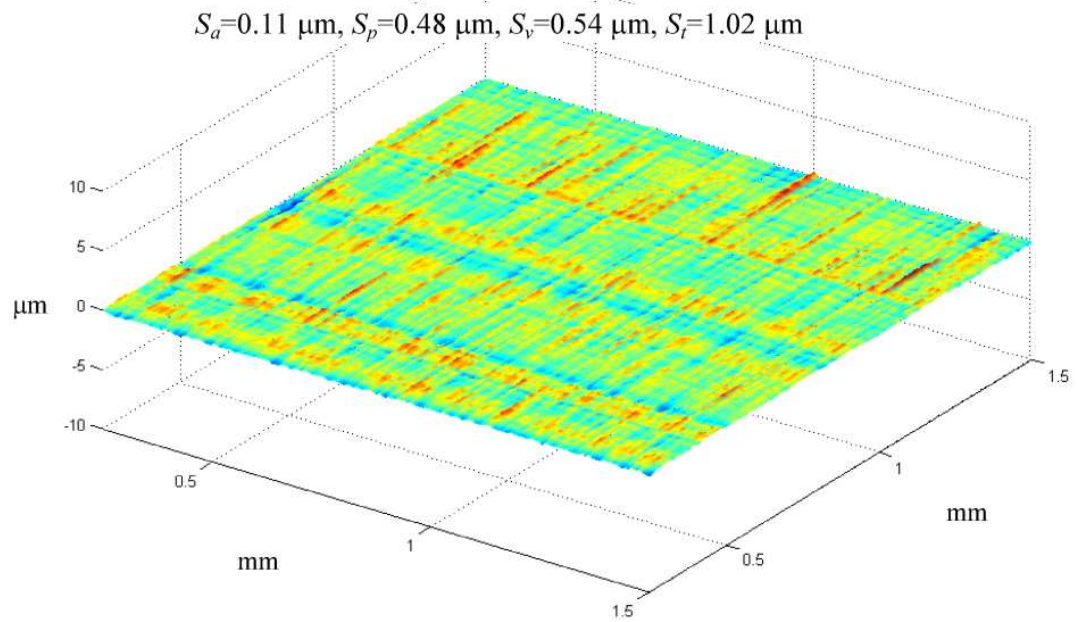

Fig. 4. The isometric image of the shaft's surface after: a) turning with the plunge feed with optimal values of cutting parameters, b) plunge grinding [18]

On the surface after turning with plunge feed a single deeper scratch is seen, which according to assumptions was generated in result of damage of the cutting edge or formation of a built-up, not eliminated by the displacement $p=0.1 \mathrm{~mm}$. In turn, the surface after plunge grinding features more homogeneous structure. 
a)

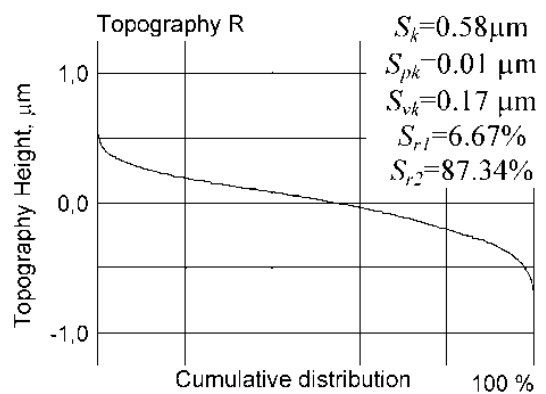

b)

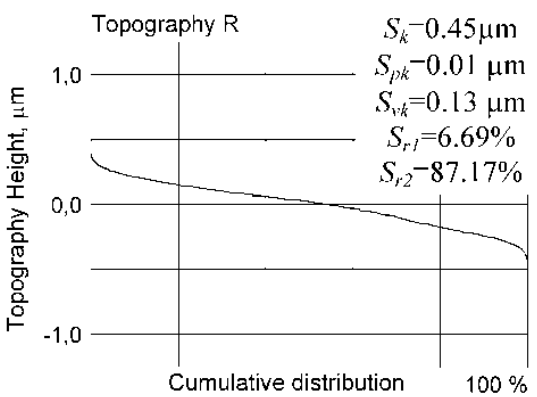

Fig. 5. The chart of the surface material portion curve: a) after turning with plunge feed, b) after plunge grinding [18]

3D surface texture obtained after finish turning with plunge feed requires further assessments, regarding mating with the radial shaft seals. Only after such investigations it would be possible to make a decision on replacement of grinding operation, using a grinding wheel and next abrasive cloth, with the finish hard turning with plunge feed.

\section{Conclusions}

The experimental research results presented here indicate that after finish hard turning with plunge feed it is possible to obtain the surface texture similar to the surface texture after plunge grinding.

Experimental research performed according to Taguchi methodology has enabled considerable reduction of quantity of carried out experiments and determination of optimal set-up of cutting parameters with respect to reduced surface roughness. Obtained results indicate, that cutting parameters have little effect on surface roughness, which is mainly shaped by cutting edge profile of cutting insert, while introduction of additional longitudinal displacement $p$ does not eliminate the deeper scratches formed previously.

Measured values of the surface roughness parameters $R_{a}, R_{z}, R_{\max }$ for the surface after turning with plunge feed are considerably smaller than those recommended by manufacturers of the radial shaft seals. However, they are close to surface roughness parameters after plunge grinding with use of a grinding wheel and abrasive cloth.

Usage of the $S_{p} / S_{t}$ and $S_{k} / S_{t}$ ratios for assessment of the surface can enable more detailed assessment of surface texture after finish turning with plunge feed and after plunge grinding, where values of these indicators are similar. 


\section{References}

[1] T. KUNSTFELD, W. HAAS: Shaft surface manufacturing methods for rotary shaft lip seals. Sealing Technology, (2005)7, 5-9.

[2] R. FLITNEY: Seals and Sealing Handbook (5th Edition). Elsevier Ltd., Amsterdam, Oxford 2007.

[3] R. VOGT, H. METZNER: Machining of shaft surfaces for radial shaft seals. Information Materials of Freudenberg Simrit GmbH \& Co. KG.

[4] DIN 3760: 1996: Rotary shaft lip type seals.

[5] DIN 3761: 1984: Rotary shaft lip type seals for automobiles.

[6] ISO 6194: 1990: Rotary shaft lip type seals.

[7] B. PYTLAK: Optymalizacja wielokryterialna operacji toczenia stali $18 \mathrm{CrMo} 4$ w stanie zahartowanym. Praca doktorska, Akademia Techniczno-Humanistyczna w Bielsku Białej, Bielsko-Biała 2007.

[8] T.G. DAWSON: Machining hardened steel with polycrystalline cubic boron nitride cutting tools. PhD thesis, Georgia Institute of Technology, Atlanta 2002.

[9] D.P. SOROKA: Hard turning and the machine tool. www.hardinge.com.

[10] K.E. OCZOŚ, W. HABRAT: Doskonalenie procesów obróbki ściernej. Mechanik, 83(2010)7, 449-452.

[11] M. KAWALEC: Efekty technologiczne obróbki na twardo materiałów metalowych. Mechanik, 79(2006)1, 20-25.

[12] M.A. FLEMING: Tooling concept for gear turning with PCBN. Industrial Diamond Review, 64(2004)602, 24-29.

[13] G. TAGUCHI: Introduction to quality engineering. Asian Productivity Organization (APO), Tokyo 1990.

[14] A. HASÇALIK, U. ÇAYDAŞ: Optimization of turning parameters for surface roughness and tool life based on the Taguchi method. The International Journal of Advanced Manufacturing Technology, 38(2008)9-10, 896-903.

[15] Wkładki ostrzowe SECOMAX PCBN zdecydowanie intensyfikują obróbkę skrawaniem. Artykuł promocyjny. Mechanik, 76(2003)11, 649-652.

[16] ISO 13565-1: 1996: Geometric Product Specification (GPS) - Surface texture: profile method - surfaces having stratified functional properties - Part 1. Filtering and general conditions.

[17] DIN EN ISO 4287: Geometrical Product Specifications (GPS) - Surface texture: Profile method - Terms, definitions and surface texture parameters.

[18] B. PYTLAK: The roughness parameters 2D and 3D and some characteristics of the machined surface topography after hard turning and grinding of hardened 18CrMo4 steel. Archiwum Technologii Maszyn i Automatyzacji, 31(2011)4, 49-58. 